\title{
Multivariate analysis of attitudes on financial and other aspects of business ethics of future managers
}

\author{
Blaženka Knežević ${ }^{1}$, Nataša Kurnoga ${ }^{1, \dagger}$ and Nika Šimurina ${ }^{1}$ \\ ${ }^{1}$ Faculty of Economics and Business, University of Zagreb, J. F. Kennedy 6, \\ 10000 Zagreb, Croatia \\ E-mail: 〈\{nkurnoga,bknezevic, nsimurina\}@efzg.hr〉
}

\begin{abstract}
Business ethics is a set of rules by which individuals and institutions behave and conduct business in a responsible manner. It involves appropriate constraints on the pursuit of self-interest and profits, particularly when actions affect other stakeholders. Research on financial and other aspects of business ethics includes an examination of personal attitudes which give insight into ways in which people tend to behave as employees, managers, taxpayers and consumers. In this research, the standard ATBEQ questionnaire was extended with five variables covering corporate social responsibility and applied to a sample of business administration students in Croatia. The aim of the research was to identify groups of future managers based on an evaluation of their attitudes on business ethics and corporate social responsibility. The analysis was divided into two parts. In the first part, factor analysis was performed on 35 variables (attitudes) relating to business ethics and corporate social responsibility. Six factors were extracted and factor scores were calculated. In the second part, hierarchical and non-hierarchical cluster analyses were conducted. Factor scores were used as input data for the cluster analysis. Firstly, the hierarchical cluster analysis was run on the calculated factor scores. According to the dendrogram, a three-cluster solution was chosen. The non-hierarchical cluster analysis was then used to improve the results of the hierarchical cluster solution. Finally, these clusters (groups) of future managers were characterised according to their attitudes on financial and other aspects of business ethics and corporate social responsibility.
\end{abstract}

Keywords: business ethics, ATBEQ, factor analysis, cluster analysis

Received: October 15, 2016; accepted: February 15, 2017; available online: March 31, 2017

DOI: 10.17535 /crorr.2017.0006

\section{Introduction}

The main objective of this paper is to explore the attitudes of future mangers' towards financial and others aspects of business ethics. To that end, a broad opinion survey was conducted among university students enrolled in business

$\dagger$ Corresponding author 
administration programmes. This approach was used by Kirchler (1999) and general ethical behaviour approach of various actors in the market starting from business people, customers towards future managers, was done by Preble and Reichel (1988), Small (1992), Sims and Gegez (2004). Current Croatian literature offers analysis of the attitudes of tax experts regarding the social aspects of tax policies, primarily the vertical equity of taxation [2] or general corporate social responsibility $[22,29]$. However, there is a scarcity of studies that apply widely accepted metrics to measure business ethics attitudes of future managers. For this research, secondary resources were scrutinized to assess which metrics and scales are used in the field of business ethics and corporate social responsibility. Based on the findings, a survey methodology was adapted and applied to a sample of future managers i.e. students at Faculty of Economics and Business Zagreb, Croatia. Then, multivariate analysis methods were used. Factor analysis was conducted to achieve data summarization and data reduction of the initial set of items. Extracted factors were used in cluster analysis aimed at identifying homogeneous groups of prospective managers.

\section{Business ethics and corporate social responsibility - over- view of the literature}

\subsection{Definitions and position of business ethics and corporate social responsibility in business economy literature}

According to Raiborn and Payne (1990), ethics can be defined as a system of value principles or practices by which an individual or organization determines what is right or wrong. Velasquez (1999) emphasizes that ethics is concerned with normative judgements involved in moral decisions as to what is good or bad. In addition, Freeman and Gilbert (1988) and Carroll (1991) add that ethics determines whether a person will act or behaviour in a fair manner.

Business ethics refers to ethical business principles, morally right decisions and actions while taking into consideration their effect on others.

Topics, such as ethics, eradicating poverty and responsibility of the business community towards different stakeholders were addressed by Benedikt Kotruljevic (or Benedetto Cotrugly) in ancient Dubrovnik in 15th century [14]. In recent times (beginning in the 20th century) business ethics has become a popular research topic in business and management literature. Preble and Reichel (1988) explain that there are two directions in researching business ethics, conceptual and empirical. Conceptual research aims to explain theoretically and clarify terminology, observe relationships and introduce guidelines for decisionmaking processes. On the other hand, empirical studies aim to test ethical behaviour of various actors in the market starting from business people, customers 
and future managers (i.e. university students enrolled in business administration programmes).

Joyner and Payne (2002) claim that the term corporate social responsibility (CSR) in management literature more often emphasizes how a business entity (i.e. company, firm, corporation or private craftsman) undertakes economic, legal, ethical and discretionary activities that are adapted to a society's values and expectations. They [12] also state that CSR and ethics are interrelated and interdependent concepts.

One of the most cited approaches in business ethics and CSR is Carroll's model of a company's social performance. Carroll (1979) claims that there are four dimensions of social performance: (1) the economic dimension - producing goods and services to sell and achieve profit; (2) the legal dimension - adhering to laws and regulations; (3) the ethical dimension -meeting society's expectations in terms of proper and righteous behaviour; and (4) the discretionary dimension undertaking activities on a voluntary and philanthropic basis in order to improvement society.

The CSR approach includes getting a company to focus on its stakeholders and society. There are numerous approaches in define a company's stakeholders. For instance, Freeman (1984) defines them as any group or individual who can influence or who is influenced by a company achieving its goals. Moir (2001) distinguish two groups of stakeholders: (1) primary stakeholders and (2) secondary stakeholders. Primary stakeholders are those who have a direct interest in a company's performance and business actions. Examples of primary stakeholders are owners, and shareholders, managers, employees, customers, and suppliers. Secondary stakeholders can influence, both positively and negatively, actions of an organization. They support a company's activities in order to achieve positive effects of business actions or hinder such actions so as to prevent negative consequences. Examples of secondary stakeholders are government agencies, regulation agencies, trade unions, labour unions, political groups, social groups, and the media.

In Croatia, some studies on business ethics and CSR [22, 26, 29] do exist. Nevertheless, this broad research area requires further efforts.

\subsection{Methodologies in researching business ethics and corpo- rate social responsibility}

A widely-used methodology is opinion surveys on various aspects of business ethics. There are numerous studies worldwide on business ethics and established methodologies used to measure individual's attitudes towards business ethics and corporate social responsibility. PRESOR (The Perceived Role of Ethics and Social Responsibility), EPQ (The Ethics Position Questionnaire) and ATBEQ (The 
Attitudes towards Business Ethics Questionnaire) are just some of these methods. The characteristics of the mentioned methodologies are given in Table 1.

\begin{tabular}{|c|c|c|c|}
\hline Characteristics & PRESOR & $\mathrm{EPQ}$ & ATBEQ \\
\hline $\begin{array}{l}\text { Full Name of } \\
\text { Methodology }\end{array}$ & $\begin{array}{l}\text { The Perceived } \\
\text { Role of Ethics } \\
\text { and Social } \\
\text { Responsibility }\end{array}$ & $\begin{array}{l}\text { The Ethics } \\
\text { Position } \\
\text { Questionnaire }\end{array}$ & $\begin{array}{c}\text { The Attitudes } \\
\text { Towards } \\
\text { Business Ethics } \\
\text { Questionnaire }\end{array}$ \\
\hline Definition/Scope & $\begin{array}{l}\text { Measures how an } \\
\text { individual } \\
\text { perceives the role } \\
\text { of ethics and } \\
\text { social } \\
\text { responsibility in } \\
\text { achieving } \\
\text { organizational } \\
\text { effectiveness }\end{array}$ & $\begin{array}{l}\text { An instrument } \\
\text { designed to } \\
\text { assess individual } \\
\text { differences in } \\
\text { relativism and } \\
\text { idealism }\end{array}$ & $\begin{array}{c}\text { An instrument } \\
\text { oriented towards } \\
\text { attitudes on } \\
\text { selection of } \\
\text { business ethics } \\
\text { situations }\end{array}$ \\
\hline $\begin{array}{l}\text { Structure of the } \\
\text { Questionnaire }\end{array}$ & $\begin{array}{l}13 \text { items, three } \\
\text { dimensions: (1) } \\
\text { social } \\
\text { responsibility and } \\
\text { profitability; (2) } \\
\text { long-term gains; } \\
\text { and (3) short- } \\
\text { term gains }\end{array}$ & $\begin{array}{l}20 \text { items, two } \\
\text { scales: }(1) \\
\text { idealism, } \\
\text { (2) relativism }\end{array}$ & $\begin{array}{l}30 \text { statements on } \\
\text { business ethics, } 5 \\
\text { point Likert scale }\end{array}$ \\
\hline $\begin{array}{l}\text { Oldest/Original } \\
\text { Paper }\end{array}$ & $\begin{array}{c}\text { Singhapakdi et } \\
\text { al. (1996) }\end{array}$ & Forsyth (1980) & $\begin{array}{c}\text { Preble and } \\
\text { Reichel (1988) }\end{array}$ \\
\hline
\end{tabular}

Source: own presentation according to $[5,6,18,20]$

Table 1: Characteristics of the methodologies applied in business ethics research studies

All these mentioned methodologies are applied to various groups of examinees and critically discussed in various studies as well as improved over time. However, in comparison to the other two methodologies, as a research instrument ATBEQ is applied on samples of business administration students as future managers in a relatively large number of countries, on various continents. We will outline only a couple of these.

For instance, Preble and Reichel (1988) developed ATBEQ and applied it to a sample of a group of management students from the USA and Israel. They performed a comparative analysis between those two groups of students and concluded that there are only a few statistically significant differences. Small (1992) applied ATBEQ on 4 student groups from 3 Western Australian 
educational institutions and a group of managers from the Australian Institute of Management (AIM), many of whom would not have been university graduates.

Kum-Lung, C. and Teck-Chai, L. (2010) applied ATBEQ on a sample of students and working adults in Malaysia and concluded that intrapersonal religiosity was a significant determinant in business ethics attitudes. They also concluded that there was no significant difference between genders, but a difference did exist for different educational levels.

Lau (2010) used ATBEQ and a set of ethical vignettes to compare students that underwent ethical training with other students. Examinees that had undergone training stated that a business ethics course should be part of the business studies curriculum.

Bageac et al. (2011) used ATBEQ on a sample of management students in France and Romania, and using depth analysis isolated five philosophical categories of future managers classified by attitudes towards ethical behaviour, specifically (1) Machiavellianism, (2) social Darwinism, (3) ethical relativism, (4) legalism and (5) moral objectivism.

A similar approach, based on ATBEQ, was applied on a sample of undergraduate students in the USA and Japan by Shields et al. (2013) who grouped Japanese and American students into five categories as suggested by Bageac et al. (2011) and drew conclusions on differences amongst them.

Price and van der Walt (2013) applied ATBEQ to South African students and made a longitudinal comparison of change over 16 years. They found out that contemporary students express stronger opinions than students in their past research. In newer research, "result based philosophies" dominate simple "ego based philosophies".

Moreover, Fatoki and Chillya (2012) applied ATBEQ to examine the attitudes of managers in SMEs in South Africa and found that a hypothesis depicting a difference between local and immigrant owners could not be proven statistically. They also observed that SME owners have strong positive attitudes towards the importance of CSR, both in improving local communities and the long-term performance of companies.

Gulova et al. (2013) conducted research on senior students in Turkey. They tested the gender perspective of business ethics and concluded that there is no significant difference between male and female students. They also performed a comparison of previous data presented in Sims and Gegez (2004). The analysis showed that business ethics preferences changed in positive direction for Machiavellianism questions and negatively for questions related to moral objectivism or Social Darwinism.

As is evident, ATBEQ is a commonly accepted research instrument in social and management science. In literature, it is mainly applied to samples of future managers i.e. management or business administration students. When applied, 
data analysis can be performed in different directions from testing national, cultural or gender differences, to longitudinal comparisons within a certain population. Therefore, we have found ATBEQ a suitable instrument for achieve the goals in our primary research and decided to apply it to students at the Faculty of Economics and Business Zagreb, Croatia. To the best of our knowledge, this methodology has not been sufficiently applied in Croatia or the Western Balkans countries.

\section{Dataset and methodology}

\subsection{Sample and questionnaire description}

Based on what has been said, ATBEQ is justifiably a benchmark methodology for research. Therefore, we will adhere to the ATBEQ methodology which has a long history with opinion surveys in the noted fields. Given that ATBEQ was developed in 1980s, we further innovated the questionnaire by adding five additional questions (variables) on corporate social responsibility attitudes, given that in Croatia this aspect has not been sufficiently researched and explained in previous research. According to previously ATBEQ-based studies, we used a multivariate analysis to explore personal values regarding business ethics and corporate social responsibility issues and views, as well as and beliefs on ones behaviour influences choices in various business situations.

The online questionnaire contained different types of questions: one choice question, multiple choice questions and Likert scale ranking questions. The online questionnaire was distributed through a social networking platform - official Facebook groups relating to courses and Google Classroom to students from various years and programmes at the Faculty of Economics and Business Zagreb, Croatia. Those students were selected as prospective future managers based on findings from previous studies [such as 1, 11, 18, 23].

The sample consisted of 224 respondents. In all, $77.7 \%$ were female and $22.3 \%$ were male students. The gender structure of the sample conformed to the student population at the various faculties of business administration and economics in Croatia. All respondents were students enrolled in various programmes covering the mentioned fields, with $38.8 \%$ in bachelor programmes, $22.8 \%$ enrolled into master's programmes, $37.9 \%$ enrolled into associate degree programmes, and only a couple from postgraduate studies. Almost $69.6 \%$ of the students work full-time or part-time, whereas $30.4 \%$ studied full-time and were not employed.

\subsection{The dataset and research methodology}

The initial dataset consists of 35 items: 30 items from the ATBEQ questionnaire and 5 items on corporate social responsibility. All the items were measured on a 
five-point Likert-type scale, anchored at 1 (strongly disagree) and 5 (strongly agree). The adequacy of multi-item scales was assessed by evaluating their reliability. Scale reliabilities were assessed by means of Cronbach's alpha coefficients. All values of Cronbach's alpha coefficients were higher than 0.7, indicating an acceptable level of reliability.

The data on 35 items (variables) were analysed using multivariate analysis methods. First, factor analysis was performed. Initial factor analysis was conducted on 35 variables relating to business ethics and corporate social responsibility. Ultimately, 16 variables with loadings less than 0.5 on all factors were excluded from further analysis. The final factor analysis was performed on 19 variables and six factors were extracted. Factor scores were calculated for these six factors and used further in the cluster analysis. Hierarchical and nonhierarchical cluster analyses were conducted. The hierarchical cluster analysis was used to choose a cluster solution and subsequently the non-hierarchical cluster analysis was used to improve the results of the chosen cluster solution. Finally, these clusters were described in line with attitudes on business ethics and corporate social responsibility.

\section{Discussion on results}

The first step in our analysis was to determine factors concerning business ethics and corporate social responsibility. For this purpose, the factor analysis of 19 variables was used. Firstly, the appropriateness of factor analysis had to be evaluated by examining the correlations and measures of sampling adequacy (MSA values). A review of the correlation matrix provided the appropriateness of the factor analysis. Furthermore, all MSA values, overall (0.75) and individually point to the appropriateness of the factor analysis. All of this leads to the conclusion that the data are appropriate for applying factor analysis and the next phase is possible, i.e. to the extraction of the factors.

The Kaiser criterion was used for factor extraction. Based on this criterion, all factors with eigenvalues are greater than one are extracted. Accordingly, six factors were extracted. However, the initial factor matrix was difficult to interpret and the factors were rotated. Varimax rotation was used and resulted in a matrix easier to interpret. These factors explain $60.03 \%$ of the total variance. Appointed factors as well as the associated variables and factor loadings are given in Table 2. As can be seen, all factor loadings are greater than 0.5 . 


\begin{tabular}{|c|c|}
\hline Factors and variables (items) & $\begin{array}{c}\text { Factor } \\
\text { loadings }\end{array}$ \\
\hline \multicolumn{2}{|l|}{ Corporate Social Responsibility } \\
\hline You should not consume more than you produce. & 0.54 \\
\hline $\begin{array}{l}\text { I fully understand the concepts of "social responsibility" and } \\
\text { "sustainability". }\end{array}$ & 0.75 \\
\hline Companies have an ethical responsibility to all stakeholders. & 0.67 \\
\hline $\begin{array}{l}\text { In the long run companies that are committed to sustainability and } \\
\text { corporate social responsibility will be more profitable than others. }\end{array}$ & 0.77 \\
\hline $\begin{array}{l}\text { Contemporary society requires that companies promote better social } \\
\text { conditions and solve social problems such as hunger, disease and } \\
\text { environmental pollution. }\end{array}$ & 0.69 \\
\hline $\begin{array}{l}\text { I would like to work for a company that has adopted sustainability } \\
\text { and corporate social responsibility as a business concept. }\end{array}$ & 0.78 \\
\hline \multicolumn{2}{|l|}{ Non-financial benefits } \\
\hline $\begin{array}{l}\text { While shopping at the supermarket, it is appropriate to switch price } \\
\text { tags or packages. }\end{array}$ & 0.64 \\
\hline As an employee, I take office supplies home; it doesn't hurt anyone. & 0.82 \\
\hline I view sick days as vacation days that I deserve. & 0.77 \\
\hline \multicolumn{2}{|l|}{ Source of Morality } \\
\hline $\begin{array}{l}\text { A person who is doing well in business does not have to worry about } \\
\text { moral problems. }\end{array}$ & 0.61 \\
\hline $\begin{array}{l}\text { Every business person acts according to moral principles, whether } \\
\text { he/she is aware of it or not. }\end{array}$ & 0.68 \\
\hline Act according to the law, and you can't go wrong morally. & 0.83 \\
\hline \multicolumn{2}{|l|}{ Self-interest } \\
\hline True morality is first and foremost self-interest. & 0.79 \\
\hline Self-sacrifice is immoral. & 0.70 \\
\hline \multicolumn{2}{|l|}{ Financial Benefits } \\
\hline $\begin{array}{l}\text { As a consumer, when making a car insurance claim, I try to get as } \\
\text { much as possible regardless of the extent of the damage. }\end{array}$ & 0.70 \\
\hline $\begin{array}{l}\text { The main interest of shareholders is maximum return on their } \\
\text { investment. }\end{array}$ & 0.67 \\
\hline $\begin{array}{l}\text { For every decision in business, the only question I ask is, "Will it be } \\
\text { profitable?" }\end{array}$ & 0.62 \\
\hline \multicolumn{2}{|l|}{ Free Market Economy } \\
\hline $\begin{array}{l}\text { Conditions of a free economy will serve best the needs of society. } \\
\text { Limiting competition can only hurt society and actually violates } \\
\text { basic natural laws. }\end{array}$ & 0.78 \\
\hline $\begin{array}{l}\text { Employee wages should be determined according to the laws of } \\
\text { supply and demand. }\end{array}$ & 0.78 \\
\hline
\end{tabular}

Table 2: Factors, variables (items) and factor loadings 
Factor scores were calculated for these six factors. These extracted factors and associated factor scores were used as input variables in cluster analysis in order to identify homogeneous groups of future managers. Figure 1 gives the hierarchical and non-hierarchical cluster analysis results, respectively the dendrogram and plot of means for each cluster.
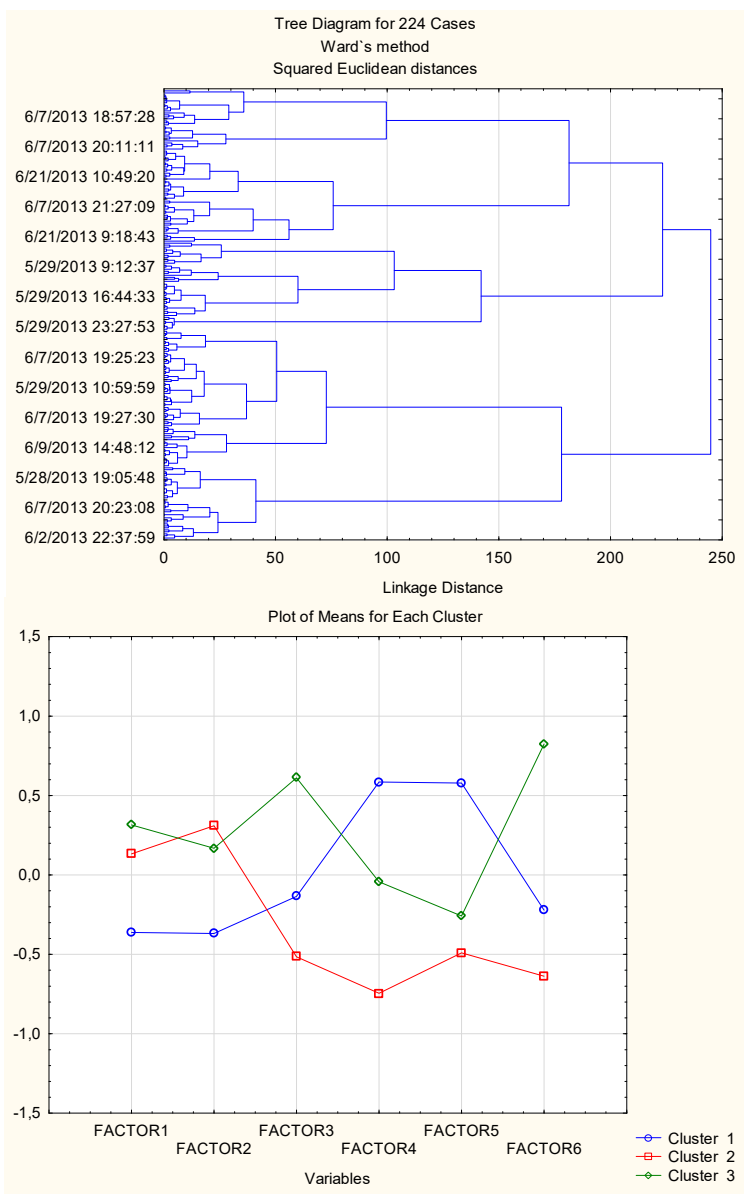

Figure 1: Dendrogram and plot of means for each cluster

First, a hierarchical cluster analysis was performed. Ward's method with squared Euclidean distances was used. According to the dendrogram given in Figure 1, it was possible to choose different solutions. Due to its best interpretative characteristics, the three-cluster solution was chosen. Finally, the non-hierarchical cluster analysis was used. The K-means method was carried out for the threecluster solution. Based on the plot of means shown in Figure 1, clusters of 
prospective managers were described according to the structure of factors related to business ethics and corporate social responsibility. Table 3 shows the characteristics of each cluster considering the structure of factors.

\begin{tabular}{|c|c|c|c|c|c|c|}
\hline & Factor 1 & Factor 2 & Factor 3 & Factor 4 & Factor 5 & Factor 6 \\
\hline & CSR & $\begin{array}{c}\text { Non- } \\
\text { Financial } \\
\text { Benefits }\end{array}$ & $\begin{array}{c}\text { Morality } \\
\text { Source }\end{array}$ & $\begin{array}{c}\text { Self- } \\
\text { Interest }\end{array}$ & $\begin{array}{c}\text { Financial } \\
\text { Benefits }\end{array}$ & $\begin{array}{c}\text { Free } \\
\text { Market }\end{array}$ \\
\hline $\begin{array}{l}\text { What is } \\
\text { more } \\
\text { ethical? }\end{array}$ & $\begin{array}{c}\text { It is } \\
\text { better to } \\
\text { have it } \\
\text { above the } \\
\text { average. }\end{array}$ & $\begin{array}{c}\text { It is } \\
\text { better to } \\
\text { have it } \\
\text { below the } \\
\text { average. }\end{array}$ & $\begin{array}{c}\text { It is } \\
\text { better to } \\
\text { have it } \\
\text { below the } \\
\text { average. } \\
\text { (In that } \\
\text { case they } \\
\text { think that } \\
\text { it is } \\
\text { necessary } \\
\text { to put } \\
\text { more } \\
\text { efforts/ } \\
\text { resources } \\
\text { into } \\
\text { morality) } \\
\text {. }\end{array}$ & $\begin{array}{l}\text { It is } \\
\text { better to } \\
\text { have it } \\
\text { below the } \\
\text { average. } \\
\text { (In that } \\
\text { case the } \\
\text { motive } \\
\text { for moral } \\
\text { behaviour } \\
\text { is not } \\
\text { selfish- } \\
\text { ness). }\end{array}$ & $\begin{array}{c}\text { It is } \\
\text { better to } \\
\text { have it } \\
\text { below the } \\
\text { average. }\end{array}$ & $\begin{array}{c}\text { It is } \\
\text { better to } \\
\text { have it } \\
\text { below the } \\
\text { average. } \\
\text { (In that } \\
\text { case they } \\
\text { agree that } \\
\text { regulation } \\
\text { is } \\
\text { necessary } \\
\text {, i.e. that } \\
\text { free } \\
\text { market } \\
\text { cannot } \\
\text { solve } \\
\text { problems } \\
\text { in } \\
\text { society). }\end{array}$ \\
\hline $\begin{array}{l}\text { Cluster } 1 \\
\text { Driven } \\
\text { by } \\
\text { financial } \\
\text { self- } \\
\text { Interest }\end{array}$ & $\begin{array}{c}\text { Below } \\
\text { the } \\
\text { average }\end{array}$ & $\begin{array}{c}\text { Below } \\
\text { the } \\
\text { average }\end{array}$ & $\begin{array}{c}\text { A little } \\
\text { bit below } \\
\text { the } \\
\text { average }\end{array}$ & $\begin{array}{c}\text { Above } \\
\text { the } \\
\text { average } \\
\text { (Highest) }\end{array}$ & $\begin{array}{c}\text { Above } \\
\text { the } \\
\text { average } \\
\text { (Highest) }\end{array}$ & $\begin{array}{c}\text { A little } \\
\text { bit below } \\
\text { the } \\
\text { average }\end{array}$ \\
\hline $\begin{array}{l}\text { Cluster } 2 \\
\text { Mainly } \\
\text { ethical }\end{array}$ & $\begin{array}{c}\text { A little } \\
\text { bit above } \\
\text { the } \\
\text { average }\end{array}$ & $\begin{array}{c}\text { A little } \\
\text { bit above } \\
\text { the } \\
\text { average } \\
\text { (Highest) }\end{array}$ & $\begin{array}{c}\text { Below } \\
\text { the } \\
\text { average } \\
\text { (lowest) }\end{array}$ & $\begin{array}{c}\text { Below } \\
\text { the } \\
\text { average } \\
\text { (lowest) }\end{array}$ & $\begin{array}{c}\text { Below } \\
\text { the } \\
\text { average } \\
\text { (lowest) }\end{array}$ & $\begin{array}{c}\text { Below the } \\
\text { average } \\
\text { (lowest) }\end{array}$ \\
\hline $\begin{array}{l}\text { Cluster } 3 \\
\text { Free } \\
\text { market } \\
\text { suppo- } \\
\text { rters }\end{array}$ & $\begin{array}{c}\text { Above } \\
\text { the } \\
\text { average } \\
\text { (Highest) }\end{array}$ & $\begin{array}{c}\text { A little } \\
\text { bit above } \\
\text { the } \\
\text { average }\end{array}$ & $\begin{array}{c}\text { Above } \\
\text { the } \\
\text { average } \\
\text { (Highest) }\end{array}$ & $\begin{array}{l}\text { Around } \\
\text { average }\end{array}$ & $\begin{array}{c}\text { A little } \\
\text { bit below } \\
\text { the } \\
\text { average }\end{array}$ & $\begin{array}{c}\text { Above } \\
\text { the } \\
\text { average } \\
\text { (Highest) }\end{array}$ \\
\hline
\end{tabular}

Table 3. Characteristics of each cluster 
Future managers from Cluster 1 (driven by financial self-interest) are oriented towards financial gain and self-interest. They do not understand and do not believe in CSR, and they also do not have confidence in the free market as does Cluster 3. Cluster 2 (mainly ethical) consists of prospective managers who understand CSR, do not believe in the power of the free market, selfishness is not a motive to act ethically, are not tolerant towards the financial benefits, but are somewhat tolerant towards non-financial benefits. In Cluster 3 (free market supporters) prospective managers understand CSR, but they are confident in the free market and are convinced that business ethics have to be supported in resources (investments). They are indifferent to personal financial and nonfinancial benefits.

\section{Conclusion}

In this research, we used factor analysis to achieve data summarization and data reduction of the initial set of items in order to use them in further analysis, i.e. cluster analysis. Factor analysis was performed and six factors were extracted: corporate social responsibility, non-financial benefits, source of morality, selfinterest, financial benefits and free market economy. The extracted factors and associated factor loadings were used as input variables in further cluster analysis in order to identify homogeneous groups of prospective managers that have similar structures of factors related to business ethics and corporate social responsibility. Hierarchical and non-hierarchical cluster analyses were conducted and a threecluster solution was chosen: the first cluster consists of respondents "driven by financial self-interest", respondents of the second cluster are "mainly ethical" and respondents from the third cluster are "free market supporters". Future research should cover both corporate social responsibility and consumer ethics. This would include the behavioral differences of individuals in respective clusters. The research was limited to university students at one institution only, and the research should be extended to other schools and other countries. In this way, the future managers would be included in a better way and the results would be more robust.

\section{Acknowledgement}

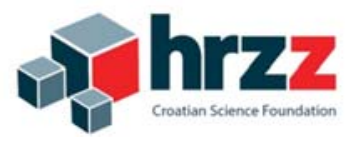

This work has been supported by Croatian Science Foundation under the project UIP-2014-09-4057 "Potentials and Obstacles of Social Supermarkets Development in Central and Eastern Europe". 


\section{References}

[1] Bageac, D., Furer O., Reynaud, E. (2011). Management students' attitudes toward business ethics: a comparison between France and Romania. Journal of Business Ethics, 98(3), 391-406.

[2] Blažić, H., Šimović, H., \& Štambuk, A. (2014). "Mjesto socijalne politike u poreznoj politici RH: Anketa poreznih stručnjaka". Revija za socijalnu politiku, (21), 3: 327-360.

[3] Carroll, A. (1979). A three-dimensional model of corporate social performance. Academy of Management Review, 4(4), 494-505.

[4] Carroll, A. B. (1991). The pyramid of corporate social responsibility: toward the moral management of organizational stakeholders. Business Horizons, 34 (4), 39-48.

[5] Davis, M. A., Andersen, M. G., Curtis, M. B. (2001). Measuring ethical ideology in business ethics: a critical analysis of the ethics position questionnaire. Journal of Business Ethics, 32 (1), pp. 35-53.

[6] Etheredge, J.M. (1999). The perceived role of ethics and social responsibility: an alternative scale structure. Journal of Business Ethics, 18 (1), 51-64.

[7] Fatoki, O., Chillya, W. (2012). An investigation into the attitudes towards business ethics and corporate social responsibility by local and immigrant SME owners in South Africa. Journal of Social Sciences, 32(1), 13-21.

[8] Forsyth, D. R. (1980). A taxonomy of ethical ideologies. Journal of Personality and Social Psychology, 39(1), 175-184.

[9] Freeman, E. (1984). Strategic management - A Stakeholder approach, Cambridge. Cambridge University Press.

[10] Freeman, R. E., Gilbert, D. E. Jr. (1988). Corporate strategy and the search for ethics. Prentice Hall, Englewood Cliffs, NJ.

[11] Gulova, A., Eryilmaz, I., Ispirli, D. (2013). Attitudes towards business ethics: an empirical study on turkish senior business students. International Proceedings of Economics Development and Research, 65(9), 42-47.

[12] Joyner, B. E., Payne, D. (2002). Evolution and implementation: a study of values, business ethics and corporate social responsibility. Journal of Business Ethics, 41 (4), 297 - 311.

[13] Kirchler, E. (1999). "Reactance to taxation: employers' attitudes towards taxes". Journal of Socio-Economics, (28), 2: 131-139.

[14] Knezevic, B.; Sukser, B.; Renko, S. (2012). Historical aspects of sustainable development in trade. The International Conference Proceedings - Trade Perspectives 2012: Trade in the Context of Sustainable Development, University of Zagreb, Faculty of Economics and Business: 1-18.

[15] Kum-Lung, C., Teck-Chai, L. (2010). Attitude towards business ethics: examining the influence of religiosity, gender and education levels. International Journal of Marketing 2(1), 226-232. 
[16] Lau, C. L. L. (2010). A step forward: ethics education matters!. Journal of Business Ethics, 92 (4), 565-584.

[17] Moir, L. (2001). What do we mean by corporate social responsibility?. Corporate Governance, 1(2), 16-22.

[18] Preble, J. F., Reichel, A. (1988). Attitudes towards business ethics of future managers in the US and Israel. Journal of Business Ethics, 12, 941-949.

[19] Price, G., van der Walt, A.J. (2013). Changes in attitudes towards business ethics held by former south african business management students. Journal of Business Ethics, 113(3), 429-440.

[20] Promislo, M. D., Giacalone, R. A., Welch, J. (2012). Consequences of concern: ethics, social responsibility and well-being. Business Ethics: A European Review, 21(2), 209-219.

[21] Raiborn, C. A., Payne, D., (1990). Corporate codes of conduct: a collective conscience and continuum. Journal of Business Ethics, 9 (11), 897-889.

[22] Renko, S., Rasic, S., Knezevic, B. (2009). Corporate social responsibility in Croatian retailing in D. Vrontis, Y. D., Weber, R.Y., Kaufmann, R., Tarba, S. (Eds.). Managerial and entrepreneurial developments in the Mediterranean area, Salerno: EuroMed Press, 1346-1358.

[23] Shields, R., Comegys, C., Lupton, R., Takei, H. (2013). Undergraduate attitudes towards business ethics: a cross-cultural comparison. Journal of Studies in Education, 3(4), 72-80.

[24] Sims, R.L., Gegez, A.E. (2004). Attitudes towards business ethics: a five nation comparative study. Journal of Business Ethics, 59(3), 253-265.

[25] Singhapakdi, A., Vitell, S. J., Rallapalli, K. C., Kraft, K. L. (1996). The perceived role of ethics and social responsibility: a scale development. Journal of Business Ethics, 15 (11), 1131-1140.

[26] Skrabalo, M., Miosic-Lisjak, N.; Bagic, A. (2007). Ubrzanje praksi društveno odgovornog poslovanja - Izvještaj o društveno odgovornom poslovanju u Hrvatskoj (Acceleration of Corporate Social Responsibility - Report on Corporate Social Responsibility in Croatia). United Nations Development Programme (UNDP): Zagreb. Available at: https://issuu.com/undphr/docs/ ubrzanje_praksi_dru_tveno_odgovorn

[27] Small, M.W. (1992). Attitudes toward business ethics held by western australlian students: A Comparative Study. Journal of Business Ethics, 11(10), 745752.

[28] Velasquez, M. G., (1999). Business ethics: cases and concepts, Prentice Hall, Englewood Cliffs, NJ.

[29] Vrdoljak Raguz, I., Hazdovac, K. (2014). Corporate social responsibility and croatian business practice. Oeconomica Jadertina, 4(1): 40-58. 